2013

\title{
Latino Racial Reporting in the US: To Be or Not To Be
}

Clara E. Rodriguez

Fordham University, crodriguez@fordham.edu

Michael Miyawaki

Fordham University

Grigoris Argeros

Mississippi State University

Follow this and additional works at: https://fordham.bepress.com/soc_facultypubs

Part of the Demography, Population, and Ecology Commons, Politics and Social Change Commons, and the Race and Ethnicity Commons

\section{Recommended Citation}

Rodriguez, Clara E.; Miyawaki, Michael; and Argeros, Grigoris, "Latino Racial Reporting in the US: To Be or Not To Be" (2013). Sociology Faculty Publications. 17.

https://fordham.bepress.com/soc_facultypubs/17 


\title{
Latino Racial Reporting in the US: To Be or Not To Be
}

\author{
Clara E. Rodríguez ${ }^{1 *}$, Michael H. Miyawaki ${ }^{1}$ and Grigoris Argeros ${ }^{2}$ \\ 1 Department of Sociology \& Anthropology, Fordham University \\ ${ }^{2}$ Department of Sociology, Mississippi State University
}

\begin{abstract}
This review focuses on how Latinos report their race. This is an area that has recently experienced a major surge of interest in both government and academic circles. This review of the literature examines how and why Latinos report their race on the census, in surveys and in more qualitative studies. It reviews the vibrant and growing scholarly literature relevant to the questions of the placement - by self or others - of Latinos along the US color line, what determines it and how the Census has coped and is coping with it. We begin with a brief review of the history of Latino classification in the census and then discuss the factors influencing racial reporting. These include national origin and skin color, acculturation and generational status, socioeconomic status, perceived discrimination and identification with others who have experienced actual discrimination, location, and question format. We end with a discussion of the implications of the recent 2010 Alternative Questionnaire Experiment conducted by the census, and conclude with suggestions for future research.
\end{abstract}

As Latinos have increased in numbers there has been increased attention paid to the long-standing issue of where Latinos stand, or are placed, on the US color line. This article focuses heavily on the racial categorization used by the US Census. We consider this an important focus for the US Census has the power to not just report racial categories, but also to create or destroy them. What becomes evident from our review of the literature is that the classification of Latinos by the Census Bureau as a distinct group bounded by notions of "race" and "ethnicity" has shifted over time with changes in the sociopolitical, cultural, and historical context of particular time periods. (Anderson 1988; Cobas et al. 2009; Omi and Winant 1994; Rodriguez 2000). Insofar as the Census Bureau has viewed "race" and "ethnicity" as two distinct entities, the process by which Latinos have been classified by the Bureau has involved overlaps between these two constructs.

There is not universal agreement as to how Latinos were counted in early censuses. (Gomez 2007; Rumbaut 2009) After the Mexican-American war, when the US acquired the southwest territories plus California, the 1850 Census counted all the residents of the New Mexico territories as white, free colored or slaves. Since slavery did not exist in these territories, 61,530 whites were counted, 17 free colored and 0 slaves (U.S. Secretary of the Interior, 1853: 160). In the 1930 decennial census an actual category for "Mexican" was introduced in the race question. But by the following decade, the "Mexican" category was removed and Mexicans were reclassified as "White" unless they were "definitely Negro, Indian, or some other race" (Foley 1997; Rodriguez 2000). From 1940 to 1970, Mexicans as well as other Latinos were counted similarly. During this same period, the Census utilized multiple measures - Spanish birth or parentage, Spanish surname, Spanish mother tongue, and a "Spanish origin" question included in the 5 percent sample of the 1970 Census - to capture and tabulate persons of "Spanish heritage" (Delgado and Stefanic 2011; Estrada et al. 1977). In the 1980 Census, the "Hispanic origin" question 
was introduced and Latinos were redefined as an ethnic group that can "be of any race" (Rodriguez 2000).

When the Hispanic identifier was introduced in the 1980 census, 58 percent of Latinos indicated "White" and, much to the surprise of the Census, 38 percent selected "other race" in the race question (U.S. Bureau of the Census 1980). (See Table 1) In the previous decade, 93 percent of Latinos were counted as "White," in a census sample and just one percent reported as "other race" (Rodriguez 2000). This difference in racial reporting was due in large part to changes in how the Census collected data on race and ethnicity; the 1970 Census was based primarily on observer classification as determined by the census enumerator, while the 1980 Census relied solely on self-identification by household members (Bennett 2000). Prior to the 1980 Census, Lee (1993) notes that Latinos who selected "other race" and wrote in a Latino referent were reassigned to a listed racial category (usually "White") by the enumerator based on appearance. However, it is unclear to what extent this happened consistently and in all field offices, as this practice was not in the fieldwork manual. After the 1980 Census results were released, the Census considered getting rid of the Hispanic origin question and making Latinos a race. However, the idea was soon dropped after strong objection from Latino constituent groups (Delgado 1986).

In the 1990 Census, the proportion of Latinos reporting "White" decreased from 58 to 52 percent and those marking "other race" increased from 38 to 43 percent. During the 1990s, the "Multiracial movement" challenged and sought change in the Census classification system. At the time, the Census only permitted respondents to check one category in the race question, a format that leaders of the movement saw as problematic for people with multiracial ancestry. With mounting pressure from the Multiracial movement for a "multiracial" category to be added to the race question, the Census commissioned three large national studies to test its effect and other changes to the racial and ethnic

Table 1. Hispanic/Latino by race, 1970-2010

\begin{tabular}{lccccc}
\hline & $\begin{array}{l}\mathbf{1 9 7 0}^{\mathbf{a}} \\
\mathbf{\%}\end{array}$ & $\begin{array}{l}\mathbf{1 9 8 0}^{\mathbf{b}} \\
\mathbf{\%}\end{array}$ & $\begin{array}{l}\mathbf{1 9 9 0}_{\mathbf{c}}^{\mathbf{c}} \\
\mathbf{\%}\end{array}$ & $\begin{array}{l}\mathbf{2 0 0 0}^{\mathbf{d}} \\
\mathbf{\%}\end{array}$ & $\begin{array}{l}\mathbf{2 0 1 0}^{\mathbf{e}} \\
\mathbf{\%}\end{array}$ \\
\hline White & 93.3 & 57.7 & 51.7 & 47.9 & 53.0 \\
Black & 5.0 & 2.7 & 3.4 & 2.0 & 2.5 \\
American Indian, Eskimo, and Aleut & 0.3 & 0.7 & 0.7 & 1.2 & 1.4 \\
Asian, Native Hawaiian, Other pacific Islander & 0.0 & 1.2 & 1.4 & 0.5 & 0.5 \\
Other Race or some Other Race & 1.3 & 37.7 & 42.7 & 42.2 & 36.7 \\
$2+$ races & - & - & - & 6.3 & 6.0 \\
Total & 100.0 & 100.0 & 100.0 & 100.0 & 100.0 \\
Total Hispanic/Latino population & $9,072,602$ & $14,603,683$ & $22,354,059$ & $35,305,818$ & $50,477,594$ \\
\hline
\end{tabular}

Sources:

aAuthors' calculation. 1970 census of Population. "Subject Reports: Persons of Spanish Origin" See http://www2.cencus.gov/prod2/decennial/documents/42043782v2p1a1cch6.pdf.

bAuthors' calculation. 1980 census of Population. "General Social and Economic Characteristics" Part 1, US Summary, PC80-1-c1. See http://www2.cencus.gov/prod2/decennial/documents/1980a_usC01.pdf.

'Authors' calculation. 1990 Census of Population. "General Population Characteristics: United States" CP-1-1 See http://www.cencus.gov/prod2/cen1990/cp1/cp-1-1.pdf.

${ }^{\mathrm{C}}$ Grieco, Elizabeth M. and Rachel C. Cassidy. 2001. "Overview of Race and Hispanic Question: 2000" See http://www.census.gov/prod/2001 pubs/c2kbr01-1pdf.

eHumes et al. 2011; " "Overview of Race and Hispanic Origin: 2010" See http://www.census.gov/prod/ cen2010/briefs/c2010br-02.pdf. 
classification format. Among the other changes proposed was one to combine the race and Hispanic origin questions again. (Rodriguez 2000). We understand that a primary driver for considering a combined Hispanic/Race combined item following the 1980 Census was the need to reduce the cost of follow up interviews. When overall findings from the studies indicated that a "combined format" resulted in a lower count of Latinos, the proposal was abandoned. Instead, the Census switched the order of the race and Hispanic origin questions, after studies revealed that the Hispanic origin question preceding the race question yielded lower "other race" responses from Latinos (Ibid).

As in the previous two decades, the Latino results from the 2000 Census were the same; 42 percent of Latinos marked "some other race" and proceeded to write in a Hispanic origin (Grieco and Cassidy 2001). Even the newly implemented measure of allowing respondents to mark more than one racial category, did not reduce the number of Latinos selecting "some other race" as the Census had hoped. With "some other race" as one of the largest and fastest growing racial categories in the United States, a new proposal emerged. Rather than combining race and Hispanic origin questions, the Census proposed to eliminate the "some other race" category from the race question altogether for the 2010 Census (Rodriguez 2009). In the end, Congressman Jose E. Serrano (D-NY) opposed the removal of the "some other race" category and conditioned funds based upon the retention of the category (Swarns 2004a,b). While the 2010 Census retained the "some other race" category, the Census did add new instructions informing respondents, "For this Census, Hispanic origins are not races" (Humes et al. 2011). Despite the additional instruction, 37 percent of Latinos reported "some other race" in the 2010 Census.

In 2010, the Census Bureau also revisited the process of classifying racial and ethnic groups with the 2010 Census Race and Hispanic Origin Alternative Questionnaire Experiment (AQE) (Compton et al. 2012). Sampling over 500,000 households - one of the largest studies ever taken by the Census - the 2010 AQE tested various questionnaire item designs and wording formats through mailed questionnaires, telephone interviews, re-interviews, and focus groups. Of the many series of questionnaire designs tested, several involved the use of a combined race and Hispanic origin question format refashioned as a "race or origin" question. The goal of the study was to improve the quality of data collection on race and ethnicity, namely decreasing the item non-response rate and the number of "some other race" responses. According to the Census Bureau, results from the study revealed an improvement in item response rate with the "combined question" formats. In other words, more people actually answered the question in the combined question panels than in the separate race and Hispanic origin question panels For purposes of this review, only the findings related to the Hispanic/Latino population are covered. Item non-response was about 1 percent in the "combined question" panels, while the item non-response rate in the separate Hispanic origin and race question panels ranged from 4.1 to 5.4 percent and 3.5 to 5.7 percent, respectively (Compton et al. 2012).

However, a question that some raise has to do with how valid and reliable such responses are, i.e., would the same respondents choose the same category if placed within a different context, e.g., applying for a job or a mortgage. Also, does checking Hispanic/Latino indicate that the person can be identified as such by others?

In addition, in terms of the "some other race" responses, the Census Bureau reported a dramatic decrease in the people choosing this category in the combined question panels relative to the "separate question" formats (Compton et al. 2012). In the separate question formats, the population reporting "some other race" ranged from 5.6 to 7.1 percent. On the other hand, with "Hispanic" as an option in the combined question panels, the 
"some other race" response dropped to about 0.2 percent. Equally important, the Census Bureau found no significant difference in the Latino count between the separate and combined question formats (Compton et al. 2012). However, when compared to the separate question formats, less detailed Hispanic origins were recorded in some of the combined question panels. Based on these major findings, the Census Bureau made several recommendations for implementations in the 2020 Census, including further testing of the combined race and Hispanic origin question refinements (Compton et al. 2012).

These findings lend further support to the complexity of classifying and identifying Latinos, a group whose pre-migration sociocultural and political experience on discourses related to "race" and "ethnicity" significantly differs from those they experience in the host country (Nakano Glenn 2009). Not surprisingly, a vibrant and growing scholarly literature has been examining the placement - by self or others - of Latinos along the US color line, what determines it and how the Census is coping with it.

\section{Factors influencing racial reporting in the census and some other race (SOR)}

The way in which Latinos have answered race questions on the census and in surveys has been enigmatic for many. Puzzling, in particular, has been the large proportion of Hispanic/Latinos who choose SOR - despite changes in the census discouraging such responses (Rodriguez 2009). The proportion of Latinos choosing SOR has varied over the last four decennial censuses, being 37.7 percent in 1980; going up to 42.7 percent in 1990, then stabilizing in 2000 at 42.2 percent and then registering lower in 2010 at 36.7 percent (Grieco and Cassidy 2001; Humes et al. 2011; U.S. Bureau of the Census 1980, 1990). (See Table 1) In contrast, in each of these last four decennial censuses the proportion of the non-Hispanic population that chose SOR was $<2$ percent. (Ibid.)

Several explanations initially surfaced to account for the large proportion of Latinos who reported themselves as "SOR" in the race question (Rodriguez 2000). Initially it was thought by some observers that Latinos chose SOR because they were "mixed race" or multiracial. Given that many Latinos can trace their ancestry to multiple origins (e.g., Indigenous, African, European, etc.), it was believed that those who checked off "other" were in fact "mestizos" or "mulattos." However, with the option to mark more than one race in the 2000 Census, only 6.3 percent of Latinos did so. Moreover, this "mark one or more" option did not substantially reduce the number of SOR responses by Latinos in 2000; fully 47 percent of Latinos indicated SOR, alone or in combination with another race (Logan 2004). Another early explanation was the assumption that Latinos misunderstood or had difficulty answering the race question (Rodriguez 2000). Misunderstanding of the question undoubtedly accounted for some SOR responses, though doubtful for all responses. While other explanations argued the large number of SOR responses resulted from the "denial of race" on the part of Latinos and the reluctance to report as Black or Indian, but not much research has been done on this (See, however, Itzigsohn et al. 2005; Rodriguez and Cordero-Guzman 1992).

A subsequent view suggested that many Latino SOR responses stemmed from Latinos having a different understanding of race (Rodriguez 2000). Past studies indicated that the concept of "race" for Latinos was not solely based on hypodescent or blood quantum (as is the case in the United States) but also involved other variables such as class, culture, appearance, education, national origin, or a combination of these and skin color (Rodriguez 1992; Rodriguez et al. 1991). Due to different racial formations in Spanish-speaking America and the Caribbean, Latino immigrants may bring with them a frame of reference that is different than the one generally used in the United States (Duany 1998; Rodriguez 2000). In essence, 
the color lines may shift somewhat as Latinos move from one context where race has been constructed in a particular way to another perhaps-geographic context.

Similarly, Roth (2012) argues that migrants bring particular racial schemas to the places to which they migrate and that as Latinos migrate to the United States, they may encounter and acquire new "racial schemas." At the same time, these immigrants can reinterpret these new schemas, blending them with old concepts or infusing them with new meaning. In today's global world, racial schemas are also exported back to immigrants' countries of origin, impacting the racial schemas existent in these countries. How Latino immigrants use racial schemas, and the variants that they create, may also influence US racial formations. Even as the Census Bureau considers changes to the current racial and ethnic classification format, racial schemas in the United States may very well be changing, reflected in part in the continued prevalence of SOR reporting by Latinos. (See Bonilla-Silva 2002; Forman et al. 2002; Vargas-Ramos 2012)

Over the years, there has been a growing body of research examining how Latinos respond to survey forms asking about their race and what particular factors are associated with their racial reporting (Campbell and Rogalin 2006; Ennis et al. 2011; Frank et al. 2010; Gallagher 2008; Golash-Boza and Darity 2008; Hirschman et al. 2000; Hitlin et al. 2007; Itzigsohn et al. 2005; Landale and Oropesa 2002; Lee and Tafoya 2006; Logan 2004; Michael and Timberlake 2008; Newby and Dowling 2007; Ortiz and Telles 2012; Rodriguez 1992, 2000; Rodriguez and Cordero-Guzman 1992; Rodriguez et al. 1991; Roth 2010; Rumbaut 2009; Saenz 2004; Stokes-Brown 2012a,b; Tafoya 2003, 2004; Taylor et al. 2012; Vaquera and Kao 2006; Vargas-Ramos 2012). This large and growing body of research examines the question of how Latinos classify themselves along various axes of the identity matrix. Some of the factors examined include national origin, skin color, nativity and generational status, language, socioeconomic status, perceived discrimination and commonality, and location. The presence of the interviewer (Choldin 1986) and different question formats, including question order, listed racial categories, response mode, and question instruction have also been found to be related to how Latinos racially report themselves (Martin 2002; Martin et al. 1990). What follows is a brief review of this research.

\section{National origin and skin color}

Studies demonstrate significant variation in Latino racial reporting by national origin. In the 2010 Census, for instance, Cubans were the most likely to report being "White" while Dominicans were the most likely to indicate "Black" or "two or more races" (Ennis et al. 2011). Salvadorans and Guatemalans had the highest proportion of "some other race" responses, and just over half of Mexicans and Puerto Ricans reported themselves as "White." These national origin differences among Latinos persisted, even after controlling for other factors that might influence racial reporting (Golash-Boza and Darity 2008; Michael and Timberlake 2008; Stokes-Brown 2012a,b; Vaquera and Kao 2006). As would be expected, skin color also affects how Latinos respond to the race question, where lighter skin increases the likelihood of a "White" identification and decreases the odds of reporting "Black" or "other" (Frank et al. 2010; Michael and Timberlake 2008; Stokes-Brown 2012a,b).

\section{Acculturation and generational status}

Researchers have also investigated whether measures of acculturation and generational status are related to how Latinos respond to the race question. The results of these studies 
have been mixed. Descriptive results suggest that both acculturation and longer exposure to the United States lower the selection of the "some other race" category and increase selections of traditional US racial categories (Lee and Tafoya 2006; Rodriguez 2000; Tafoya 2003, 2004; and see Rumbaut 2009 for the exception). However, findings from multivariate analysis are less consistent. While some scholars find that nativity and generational status are negatively associated with "other race" reporting and positively related to "White" responses (Stokes-Brown 2012a,b; Vaquera and Kao 2006), others report that longer duration in the United States decreases "White" identification and increases the odds of opting out of traditional categories in the race question and choosing SOR (Frank et al. 2010; Michael and Timberlake 2008). Furthermore, still others have found that bilingual and English dominant Latinos are more likely to provide "some other race" responses as compared to those who are Spanish dominant (Frank et al. 2010; GolashBoza and Darity 2008; Michael and Timberlake 2008; Stokes-Brown 2012a,b).

\section{Socioeconomic status}

Social class plays an important role in racial identification in Latin America (Rodriguez 2000; Wade 1997). Some argue that socioeconomic status can sometimes trump skin color in so far as dark-skinned Latinos can become "White" with upward mobility, though others maintain that only people who are racially ambiguous can experience "social whitening" (Telles 2004). There has been some support for the social whitening thesis among Latinos in the United States, whereby higher educational and income attainment is associated with reporting "White" in the race question (Stokes-Brown 2012a,b; Tafoya 2004) or with a White phenotype or color (Allen et al. 2000; Murguia and Telles 1996; Telles and Murguia 1990, 1992). On the other hand, findings in Golash-Boza and Darity (2008) are mixed and other studies show that socioeconomic status is unrelated to Latinos experiencing social whitening (Frank et al. 2010; Michael and Timberlake 2008). In fact, Michael and Timberlake (2008) report that higher family income decreases the propensity for Latinos to report being "White," and Itzigsohn and colleagues (2005) point out that lower occupational status is associated with "White" identification for Dominican immigrants.

\section{Perceived discrimination and commonality}

Discrimination, whether experienced or perceived, appears to significantly impact Latino racial reporting. Studies find that Latinos who experienced or perceived discrimination are less likely to indicate being "White" and more likely to mark "Black" or "other" in the race question (Golash-Boza and Darity 2008; Itzigsohn et al. 2005; Stokes-Brown 2012a,b). Golash-Boza and Darity (2008) posit that these differences in racial reporting point to Latino experiences with "racialized assimilation," such that skin color shapes their experience in the United States and possible encounters with discrimination. Findings by Stokes-Brown $(2012 \mathrm{a}, \mathrm{b})$ corroborate this assertion; Latinos who experienced discrimination because of their skin color were more likely to select "Black" or "some other race" in the race question. In addition to discrimination, perceived commonality or linked fate with Blacks or Whites can also influence the ways in which Latinos racially report themselves. Stokes-Brown (2012a,b) notes that Latinos who perceive commonality with Blacks are more likely to report being "some other race," whereas those who find commonality with whites are more likely to identify as "White." 


\section{Location}

Local and regional racial compositions have also been found to affect Latino responses to survey questions about their race. Research by Logan (2004) reveals that Latinos reporting "Black," "White," or "some other race" correspond to increases in Black, White, and Latino populations, respectively, in their local geographic area. Vaquera and Kao (2006) also find evidence that school racial/ethnic composition influences how Latino youth racially identify. Moreover, metropolitan and state-level analyses demonstrate significant variation in Latino racial reporting even by national origin groups (Itzigsohn et al. 2005; Ortiz and Telles 2012; Rumbaut 2009). For instance, Ortiz and Telles (2012) find that Mexicans in San Antonio are significantly less likely than Mexicans in Los Angeles to report "some other race," net of other variables. Lastly, at the regional level, Frank et al. (2010) report that Latinos in the South are more likely than those in the Southwest to select traditional racial categories and less likely to indicate "some other race." These scholars attribute these patterns to differences in the social, political, and cultural milieu in which Latinos live.

\section{Question format}

In addition to the above factors, studies show that question order, listed racial categories, response mode, and question instruction all influence Latino racial reporting. Surveys have found that Latinos are less likely to report "other race" when the Hispanic origin question precedes the race question (Hirschman et al. 2000; Rodriguez 2000). Hitlin et al. (2007) find that Latinos gravitate towards the "White" category when the "other race" category is not listed as an option. Moreover, the authors find that Latinos are more likely to indicate "White" and less likely to skip the race question in an interviewer-assisted survey as opposed to a self-administered survey. There is also evidence suggesting that question instruction can influence racial responses from Latinos (Martin 2002; Martin et al. 1990). One example of how question format can influence Latino responses can be seen in Table 2, which shows reported race for Latino head of households by survey year from the 2005-2009 American Community Surveys (ACS). Starting in 2008, there is a notable increase in "White" responses and a sharp decrease in "some other race" responses. Coincidentally, 2008 was the year the Census Bureau added the instruction, "For this census, Hispanic origins are not races," in both the ACS and 2010 Census (Humes et al. 2011). This shift in racial reporting among Latinos could be attributed in part to the addition of a sentence instructing respondents not to report "Hispanic origins" as races.

The 2010 AQE and the Combined Race/Hispanic Origin Question Format With the recent announcement of the 2010 AQE findings, the Census Bureau is considering making changes to the current racial and ethnic classification format. One of the changes recommended by the Census Bureau includes combining the race and Hispanic origin questions. So instead of one question asking whether or not the respondent is Hispanic and a second question asking about their race, the "Hispanic/Latino" category would be placed in the same question as the one asking for respondent's "race." The decision to combine the two questions may be complicated by the fact there are multiple constituencies that rely on these data, each with different goals and therefore, different criteria for choosing the "best" question format (Campbell and Rogalin 2006). For instance, the combined question format could raise questions for constituent groups concerned with Latino undercounts. Previous studies have found that the "combined format" led to lower counts 
Table 2. Reported race among Latino head of households by survey year, American Community Surveys 2005-2009

\begin{tabular}{|c|c|c|c|c|c|c|}
\hline & $\begin{array}{l}2005 \\
\%\end{array}$ & $\begin{array}{l}2006 \\
\%\end{array}$ & $\begin{array}{l}2007 \\
\%\end{array}$ & $\begin{array}{l}2008^{a} \\
\%\end{array}$ & $\begin{array}{l}2009 \\
\%\end{array}$ & $\begin{array}{l}\text { Total } \\
\%\end{array}$ \\
\hline \multicolumn{7}{|l|}{ Race } \\
\hline White & 55.5 & 53.7 & 55.2 & 64.0 & 64.4 & 58.8 \\
\hline Black & 1.5 & 1.4 & 1.6 & 2.0 & 2.0 & 1.7 \\
\hline American Indian, Eskimo, and Aleut & 0.9 & 0.9 & 0.9 & 1.0 & 1.0 & 0.9 \\
\hline $\begin{array}{l}\text { Asian, Native Hawaiian, } \\
\text { Other pacific Islander }\end{array}$ & 0.5 & 0.5 & 0.4 & 0.5 & 0.4 & 0.5 \\
\hline Other Race or Some Other Race & 39.8 & 40.8 & 39.2 & 29.6 & 29.1 & 35.3 \\
\hline $2+$ Races & 2.7 & 2.8 & 2.7 & 2.9 & 3.1 & 2.8 \\
\hline Total & $2,125,174$ & $2,278,363$ & $2,336,764$ & $2,421,601$ & $2,492,320$ & $11,654,221$ \\
\hline
\end{tabular}

Note: Percentages are weighted and may not add up to 100 percent due to rounding.

Source: 2005-2009 American Community Survey (Ruggles et al. 2010).

aThe year Census Bureau added the instruction, "For this census, Hispanic origins are not races," In the American Community Survey and 2010 Cences (Humes et al. 2011).

of Latinos (Campbell and Rogalin 2006). Moreover, research continues to document considerable inequality by Latinos' reported race in terms of education (Logan 2004; Rodriguez 1990; Tafoya 2004), earnings and income (Cotton, 1993; Rodriguez 1990, 1991; Rodriguez et al. 2012), housing (Denton and Massey 1989; Iceland and Nelson 2008; Logan 2004; Rosenbaum 1996), health (Borrell and Crawford 2006; Borrell and Rodriguez 2010; LaVeist et al., 2011), and political engagement (Basler 2008; Masuoka 2008; Stokes-Brown 2006, 2009, 2012b). According to Hernández (2012), combining race and Hispanic origin questions would result in the inability to capture these racial differences within Hispanic/Latino groups - even if respondents are allowed to choose more than one race category, for many Latinos do not want to acknowledge racial mixture. There are also some concerns raised by Black organizations and scholars that the combined question is a conceptual change moving the Black race to an ethnicity (African American).

\section{Combined race/ ethnicity format}

At the same time, however, many Latinos opt out of traditional categories in the race question by selecting "some other race" and writing in a Latino referent, (e.g., their nationality). Furthermore, due to the profound racialization of Latinos in the United States (See Cobas et al. 2009), some suggest that "Latino" is emerging as a "racial" category (Rumbaut 2009). As a result, a number of researchers are calling for the use of a combined race/ethnicity format (Allen et al. 2011; Haney Lopez 2005; Hitlin et al. 2007; Lee and Tafoya 2006; Pimentel and Balzhiser 2012). Given that Latinos constitute the largest minority group, political stakes are high in terms of how Latinos should be counted and what classification format should be used. As such, those concerned with primary identification may advocate the combined format, while those interested in maximizing the Latino count (and subsequently the group's political power) may call for the separate race and ethnicity design. Finally, those focused on racial differences within the Latino community may resist the combined race/ethnicity question, as it would yield far less "racial" data (Campbell and Rogalin 2006). 


\section{Conclusions and future directions in research}

\section{Racial reporting and national origin differences}

The generic "Hispanic" census category overshadows the growing heterogeneity characterizing the Latino/-a population in the United States. As noted above, a key feature of this diversity pertains to the group's racial identification and reporting on various surveys, including those administered by the Census. As Table 1 indicates, the 2010 Census revealed that 53 percent of Latinos identify as White, which represents about a 5 percent drop from 58 percent in 1980 (Humes et al. 2011; Logan 2004). Moreover, despite a decline in 2010 due to wording changes, nearly four out of ten Latinos identified as "some other race" (Ennis et al. 2011). In addition, the increasing diversity in national origin of the Latino population is also evident from a recent survey on Hispanic identity. Here the majority of respondents identified with their family's country of origin instead of the broad generic "Latino" category. Furthermore most (51 percent) respondents identified as "some other race" (Taylor et al. 2012). As in the case of the Asian American group, which is also extremely heterogeneous with regard to national origin, future research needs to acknowledge this diversity and be cognizant of the differences, as well as the commonalities among groups.

\section{Multiple measure of race to study Latinos}

Several studies demonstrate that how Latinos racially report themselves does not always correspond with how they are racially classified by others (Campbell and Troyer 2007; Itzigsohn et al. 2005; Rodriguez and Cordero-Guzman 1992; Roth 2010).). In a study of Dominican immigrants, Itzigsohn et al. (2005) find that the majority of their Dominican respondents do not identify in "Black" and "White" terms. However, when asked about their beliefs concerning how they are perceived in the United States, the modal response is "Black." Called "perceptual dissonance" (Rodriguez 2000), these differences in self-identification and observer classification (actual or perceived) carry important implications when studying population groups, including Latinos (Jones et al. 2008; Roth 2010). Depending on the measure of race used, different conclusions can be made about racial inequality (Saperstein 2012). Future studies on Latinos and race should incorporate, where possible, multiple measures of race including self-reports and observer classification. This may be more possible in qualitative studies (Roth 2012), but survey researchers may want to consider using more than one question to ask about Latino race, e.g., they may want to ask how Latinos classify themselves racially, as well as how Latinos think others classify them racially. Or, they may want to ask a question on ancestry or birthplace.

\section{Racial identity of the offspring of Latino intermarriage}

Since 1970, Latino intermarriage has been on the rise in the United States (Lee and Edmonston 2005). While rates of Latinos married to non-Latinos have remained fairly steady and relatively high over the years, Latino/non-Latino White couples account for over 40 percent of all interracial/interethnic marriages among "newlyweds" (Passel et al. 2010). With increases in Latino intermarriage, the number of children living in Latino/non-Latino households has also increased (Lee and Edmonston 2005). Indeed, in California, "part-Latinos" make up more than two-thirds of multiracial/multiethnic births 
(Tafoya 2002). Previous studies have examined the "ethnic" identity of people of partial Latino ancestry (Jimenez 2004; Lee and Edmonston 2005, 2006; Qian 2004). However, research has only begun to fully investigate the "racial" identity of part-Latinos (See Herman and Castilla 2010; Lee and Bean 2007, 2010; Romo 2011). In most studies the children of intermarried couples have their race/ethnicity decided by their parents. An important issue that will arise in the near future is how these children will respond when they choose their race/ethnicity. This has not been fully studied. Future research should consider the racial identity experience of this growing population as well as how they, too, report themselves in survey forms asking about their race.

\section{Race within families}

It is now fairly common knowledge that many Latino families have a wide spectrum of physical types. There is reference in the literature to the fact that how one was, or is, viewed within one's family, e.g., as either the lightest one or the darkest one, influences the way in which Latinos view themselves and report their race. Yet, there is not much research examining Latino race reporting within families. It is often difficult to interview all the members of one family and so this type of quantitative or qualitative data is often difficult to come by. However, it is important to do research along this line as it should provide insights into how and why Latinos report their race in the way that they do. This research should also include longitudinal studies of Latino racial identity, so as to measure change over time, if any.

As we have seen, Hispanic racial identification is influenced by a host of factors. National origin, socioeconomic status, acculturation levels, family/household characteristics, metropolitan/neighborhood context, and experience with discrimination are all associated with differences in racial identification (Campbell and Rogalin 2006). Insofar as racial categories are socially constructed and contingent upon the socioeconomic, political and cultural contexts that give rise to such categories, the aforementioned factors, coupled with the growing Latino population size, will most likely continue to drive scholars to redefine and re-evaluate the discourse on issues pertaining to Hispanic/Latino identity.

\section{Short Biographies}

GrigorisArgeros is an Asst. Prof. of Sociology at Mississippi State University. His research focuses on both the correlates and consequences of patterns of racial/ethnic neighborhood change, and changes in levels of residential segregation. His work also examines the relationship between race and class as it pertains to racial/ethnic group locational attainment outcomes.

Michael Miyawaki is currently a Ph.D. candidate in sociology at Fordham University. His research interests include race and ethnicity, stratification and inequality, Latino studies, and mixed race studies. His dissertation focuses on the racial identity of the offspring of Latino/non-Latino White, Black, and Asian intermarriages.

Clara E. Rodríguez's current research focuses on the intersection of popular global media and race/ethnicity. She is the author of numerous articles and several books including: Heroes, Lovers and Others (Washington, D. C.: Oxford University Press, 2008; Smithsonian Institution Press, 2004); Changing Race: Latinos, The Census and the History of Ethnicity in the United States;Hispanics in the Labor Force: Issues and Policies, with Meléndez, E. and Barry Figueroa, J. (Eds.); Puerto Ricans: Born in the USA; and Latin Looks: Images of 
Latinas and Latinos in U.S. Media; andco-author of The Culture and Commerce of Publishing in the 21st Century, Stanford University Press, 2007; Bejing: Renmin University Press).

\section{Note}

^ Correspondence address: Dr. Clara E. Rodríguez, Fordham University, Dept. of Sociology \& Anthropology, 113

W. 60 St., New York, NY 10023, USA. Email: crodriguez@fordham.edu

\section{References}

Allen, Jr. Vincent C., Christina Lachance, Britt Rios-Ellis and Kimberly A. Kaphingst. 2011. 'Issues in the Assessment of 'Race' Among Latinos: Implications for Research and Policy.' Hispanic Journal of Behavioral Science 33: 411-24.

Allen, Walter, Edward Telles and Margaret Hunter. 2000. 'Skin Color, Income and Education: A Comparison of African Americans and Mexican Americans.' National Journal of Sociology 12: 129-80.

Anderson, Margo J. 1988. The American Census: A Social History. New Haven, CT: Yale University Press.

Basler, Carleen. 2008. 'White Dreams and Red Votes: Mexican Americans and the Lure of Inclusion in the Republican Party.' Ethnic and Racial Studies 31: 123-66.

Bennett, Claudette. 2000. 'Racial Categories Used in the Decennial Censuses, 1790 to the Present.' Government Information Quarterly 17: 161-80.

Bonilla-Silva, Eduardo. 2002. 'We are All Americans! The Latin Americanization of Racial Stratification in the USA.' Race and Society 5: 3-16.

Borrell, Luisa N. and Natalie D. Crawford. 2006. 'Race, Ethnicity, and Self-Rated Health Status in the Behavioral Risk Factor Surveillance System Survey.' Hispanic Journal of Behavioral Sciences 28: 387-403.

Borrell, Luisa N. and Clara E. Rodriguez. 2010. 'The Implications and Impact of Race on the Health of Hispanics or Latinos.' Pp. 32-52 in Health Issues in Latino Males: A Social and Structural Approach, edited by Marilyn Aguirre-Molina, Luisa N. Borrell and William Vega. New Brunswick, NJ: Rutgers University Press.

Campbell, Mary E. and Christabel L. Rogalin. 2006. 'Categorical Imperatives: The Interaction of Latino and Racial Identification.’ Social Science Quarterly 87: 1030-52.

Campbell, Mary E. and Lisa Troyer. 2007. 'The Implications of Racial Misclassification by Observers.' American Sociological Review 72: 750-65.

Choldin, Harvey M. 1986. 'The 'Hispanic Issue' in the 1980 Census.' Demography 23: 403-18.

Cobas, Jose A., Jorge Duany and Joe R. Feagin (eds). 2009. How the U.S. Racializes Latinos: White Hegemony and its Consequences. Boulder, CO: Paradigm Publishers.

Compton, Elizabeth, Michael Bentley, Sharon Ennis and Sonya Rastogi. 2012. 2010 Census Race and Hispanic Origin Alternative Questionnaire Experiment. [Online]. Retrieved on 20 August 2012 from: http://2010.census.gov/ 2010 census/pdf/2010\%20Census\%20Race\%20and\%20Hispanic\%20Origin\%20Alternative\%20Questionnaire\%20Experiment.pdf

Cotton, Jeremiah. 1993. 'Color or Culture?: Wage Differences among Non-Hispanic Black Males, Hispanic Black Males and Hispanic White Males.' Review of Black Political Economy 21: 53-67.

Delgado, Dora. 1986. 'Census Advisors Finally Meet.' Hispanic Link Weekly Report 4: 1-2.

Delgado, Richard and Jean Stefanic (eds). 2011. The Latino/A Condition: A Critical Reader, 2nd edn. New York: New York University Press.

Denton, Nancy. A. and Douglas S. Massey. 1989. 'Racial Identity Among Caribbean Hispanics: The Effect of Double Minority Status on Residential Segregation.' American Sociological Review 54:790-808.

Duany, Jorge. 1998. 'Reconstructing Racial Identity: Ethnicity, Color and Class among Dominicans in the United States and Puerto Rico.' Latin American Perspectives 25: 147-72.

Ennis, Sharon R., Merarys Rios-Vargas and Nora G. Albert. 2011. 'The Hispanic Population: 2010.' [Online]. 2010 Census Briefs. Retrieved on 3 September 2012 from: http://www.census.gov/prod/cen2010/briefs/c2010br-04.pdf

Estrada, Leo F., Jose Hernandez and David Alvirez. 1977. 'Using Census Data to Study the Spanish Heritage Population of the United States.' Pp. 13-59 in Cuantos Somos: A Demographic Study of the Mexican American Population, edited by Charles H. Teller, et al. Austin, TX: The University of Texas, Center for Mexican American Studies, Monograph No. 2.

Foley, Neil. 1997. 'Becoming Hispanic: Mexican Americans and the Faustian Pact with Whiteness.' Pp. 53-70 in Reflexiones: New Directions in Mexican American Studies, edited by Neil Foley. Austin, TX: Center for Mexican American Studies, University of Texas at Austin.

Forman, Tyrone, Carla Goar and Amanda E. Lewis. 2002. 'Neither Black nor White? An Empirical Test of the Latin Americanization Thesis.' Race \& Society 5: 65-84.

Frank, Reanne, Ilana Redstone Akresh and Bo Lu. 2010. 'Latino Immigrants and the U.S. Racial Order: How and Where Do They Fit In?’ American Sociological Review 75: 378-401. 
Gallagher, Charles A (ed). 2008. Racism in Post-Race America: New Theories, New Directions. Chapel Hill, NC: Social Forces Publishing.

Golash-Boza, Tanya and William Darity Jr. 2008. 'Latino Racial Choices: The Effects of Skin Colour and Discrimination on Latinos' and Latinas' Racial Self-Identifications.' Ethnic and Racial Studies 31:899-934.

Gomez, Laura E. 2007. Manifest Destinies: The Making of the Mexican American Race. New York: New York University Press.

Grieco, Elizabeth M. and Rachel C. Cassidy. 2001. 'Overview of Race and Hispanic Question: 2000.' U.S. Census Bureau, Census 2000 Brief, C2KBR/0101, March 2001.

Haney Lopez, Ian. 2005. 'Race on the 2010 Census: Hispanics and the Shrinking White Majority.' Daedalus 134: $42-52$.

Herman, Melissa R. and Maria L. Castilla. 2010. 'Appearance and Social Class: An In-Depth Look at Multiracial Hispanic Youth.’ Pp. 145-62 in Multiracial Americans and Social Class: The Influence of Social Class on Racial Identity, edited by Kathleen Odell Korgen. Westport, CT: Praeger.

Hernández, Tanya K. 2012. "Census Racial Categories and the Latino "Culture" of Black Invisibility, SALTLAW Blog, (October 25, 2012).' Reprinted as a guest column in National Institute for Latino Policy, National Institute for Latino Policy, Latino Census Network. [Online]. Retrieved on 27 October 2012 from: census@latinopolicy.org, .

Hirschman, Charles, Richard Alba and Reynolds Farley. 2000. 'The Meaning and Measurement of Race in the U.S. Census: Glimpse into the Future.' Demography 37: 381-93.

Hitlin, Steven J., Scott Brown and Glen H. Elder Jr. 2007. 'Measuring Latinos: Racial vs. Ethnic Classification and Self-Understanding.' Social Forces 86: 587-611.

Humes, Karen R., Nicholas A. Jones and Roberto R. Ramirez. 2011. 'Overview of Race and Hispanic Origin: 2010. ' [Online]. 2010 Census Briefs. Retrieved on 3 September 2012 from: http://www.census.gov/prod/cen2010/ briefs/c2010br-02.pdf

Iceland, John and Kyle Ann Nelson. 2008. 'Hispanic Segregation in Metropolitan America: Exploring the Multiple Forms of Spatial Assimilation.' American Sociological Review 73: 741-65.

Itzigsohn, Jose, Silvia Giorguli and Obed Vazquez. 2005. 'Immigrant Incorporation and Racial Identity: Racial Self-Identification among Dominican Immigrants.' Ethnic and Racial Studies 28: 50-78.

Jimenez, Tomas R. 2004. 'Negotiating Ethnic Boundaries: Multiethnic Mexican Americans and Ethnic Identity in the United States.' Ethnicities 4: 75-97.

Jones, Camara Phyllis, Benedict I. Truman, Laurie D. Elam-Evans, Camille A. Jones, Clara Y. Jones, Ruth Jiles, Susan Rumisha and Geraldine S. Perry. 2008. 'Using 'Socially Assigned Race' to Probe White Advantages in Health Status.' Ethnicity \& Disease 18: 496-504.

Landale, Nancy S. and R.S. Oropesa. 2002. 'White, Black, or Puerto Rican? Racial Self-Identification among Mainland and Island Puerto Ricans.' Social Forces 81: 231-54.

LaVeist-Ramos, T., J. Galarraga, R. Thorpe Jr, C. Bell and C. Austin. 2011. 'Are black Hispanics black or Hispanic? Exploring Disparities at the Intersection of Race and Ethnicity.' Journal of Epidemiological Community Health 10: 1136. 1-5.

Lee, Jennifer and Frank D. Bean. 2007. 'Reinventing the Color Line: Immigration and America's New Racial/Ethnic Divide.' Social Forces 86: 561-86.

Lee, Jennifer and Frank D. Bean. 2010. The Diversity Paradox: Immigration and the Color Line in Twenty-First Century America. New York: Russell Sage Foundation.

Lee, Sharon M. 1993. 'Racial Classification in the US Census: 1890-1990.' Ethnic and Racial Studies 16: 75-94.

Lee, Sharon M. and Barry Edmonston. 2005. 'New Marriages, New Families: U.S. Racial and Hispanic Intermarriage.' Population Bulletin 60: 1-36.

Lee, Sharon M. and Barry Edmonston. 2006. 'Hispanic Intermarriage, Identification, and U.S. Latino Population Change.' Social Science Quarterly 87: 1263-79.

Lee, Sharon M. and Sonya M. Tafoya. 2006. 'Rethinking US Census Racial and Ethnic Categories for the 21st Century.' Journal of Economic and Social Measurement 31: 233-52.

Logan, John R. 2004. 'How Race Counts for Hispanic Americans.' Sage Race Relations Abstracts 29: 7-19.

Martin, Elizabeth, Theresa J. De Maio and Pamela C. Campanelli. 1990. 'Context Effects for Census Measures of Race and Hispanic Origin.' Public Opinion Quarterly 54: 551-66.

Masuoka, Natalie. 2008. 'Defining the Group: Latino Identity and Political Participation.' American Politics Research 36: 33-61.

Michael, Joseph and Jeffrey M. Timberlake. 2008. 'Are Latinos Becoming White? Determinants of Latinos' Racial Self-Identification in the U.S.' Pp. 107-22 in Racism in Post-Race America: New Theories, New Directions, edited by Charles A. Gallagher, Chapel Hill, NC: Social Forces Publishing.

Murguia, Edward and Edward. E. Telles. 1996. 'Phenotype and schooling among Mexican Americans.' Sociology of Education 69: 276-89.

Nakano Glenn, Evelyn (ed). 2009. Shades of Difference: Why Skin Color Matters. Stanford, CA: Stanford University Press. 
Newby, Alison C. and Julie A. Dowling. 2007. 'Black and Hispanic: the Racial Identification of Afro-Cuban Immigrants in the Southwest.' Sociological Persectives 50: 343-66.

Omi, Michael and Howard Winant. 1994. Racial Formation in the United States: From the 1960s to the 1990s. New York: Routledge.

Ortiz, Vilma and Edward Telles. 2012. 'Racial Identity and Racial Treatment of Mexican Americans.' Race and Social Problems 4: 41-56.

Passel, Jeffrey S., Wendy Wang and Paul Taylor. 2010. Marrying Out: One-in-Seven New U.S. Marriages Is Interracial or Interethnic. Washington, DC: Pew Research Center.

Pimentel, Charise and Deborah Balzhiser. 2012. 'The Double Occupancy of Hispanics: Counting Race and Ethnicity in the U.S. Census.' Journal of Business and Technical Communication 26: 311-39.

Rodriguez, Clara E. 1990. 'Racial Classification among Puerto Rican Men and Women in New York City.' Hispanic Journal of Behavioral Sciences 12: 366-79.

Rodriguez, Clara E. 1991. 'The Effects of Race on Puerto Rican Wages.' Pp. 77-98 in Hispanics in the Labor Force: Issues and Politics, edited by Edwin Melendez, Clara Rodriguez and Janis Barry Figueroa. New York: Plenum Press.

Rodriguez, Clara E. 1992. 'Race, Culture, and Latino 'Otherness' in the 1980 Census.' Social Science Quarterly 73: 930-7.

Rodriguez, Clara E. 2000. Changing Race: Latinos, the Census, and the History of Ethnicity in the United States. New York: New York University Press.

Rodriguez, Clara E. 2009. 'Counting Latinos in the U.S. Census.' Pp. 37-53 in How the United States Racializes Latinos: White Hegemony and Its Consequences, edited by Jose A. Cobas, Jorge Duany and Joe R. Feagin. Boulder, CO: Paradigm Publishers.

Rodriguez, Clara E., Grigoris Argeros and Michael H. Miyawaki. 2012. 'Does Race and National Origin Influence the Hourly Wages that Latino Males Receive?' Pp. 207-18 in Invisible No More: Understanding the Disenfranchisement of Latino Men and Boys, edited by Pedro Noguera, Aida Hurtado, and Edward Fergus, New York: Routledge Press.

Rodriguez, Clara E., Aida Castro, Oscar Garcia and Analisa Torres. 1991. 'Latino Racial Identity: In the Eye of the Beholder?' Latino Studies Journal 2: 33-48.

Rodriguez, Clara E. and Hector Cordero-Guzman. 1992. 'Placing Race in Context.' Ethnic and Racial Studies 15: 523-42.

Romo, Rebecca. 2011. 'Between Black and Brown: Blaxican (Black-Mexican) Multiracial Identity in California.' Journal of Black Studies 42: 402-26.

Rosenbaum, Emily. 1996. 'The Influence of Race on Hispanic Housing Choices: New York City, 1978-1987.' Urban Affairs Review 32: 217-43.

Roth, Wendy D. 2010. 'Racial Mismatch: The Divergence Between Form and Function in Data for Monitoring Racial Discrimination of Hispanics.' Social Science Quarterly 91: 1288-311.

Roth, Wendy D. 2012. Race Migrations: Latinos and the Cultural Transformation of Race. Stanford, CA: Stanford University Press.

Ruggles, Steven, J. Trent Alexander, Katie Genadek, Ronald Goeken, Matthew B. Schroeder and Matthew Sobek. 2010. Integrated Public Use Microdata Series: Version 5.0. Minneapolis, MN: Minnesota Population Center.

Rumbaut, Ruben G. 2009. 'Pigments of Our Imagination: On the Racialization and Racial Identities of 'Hispanics' and 'Latinos." Pp. 15-36 in How the U.S. Racializes Latinos: White Hegemony and its Consequences, edited by Jose A. Cobas, Jorge Duany and Joe R. Feagin. Boulder, CO: Paradigm Publishers.

Saenz, Rogelio. 2004. Latinos and the Changing Face of America. New York and Washington, DC: Russell Sage Foundation and Population Reference Bureau.

Saperstein, Aliya. 2012. 'Capturing Complexity in the United States: Which Aspects of Race Matter and When?' Ethnic and Racial Studies 35: 1484-502.

Stokes-Brown, Atiya Kai. 2006. 'Racial Identity and Latino Vote Choice.' American Politics Research 34: 627-52.

Stokes-Brown, Atiya Kai. 2009. 'The Hidden Politics of Identity: Racial Self-Identification and Latino Political Engagement.' Politics \& Policy 37: 1281-305.

Stokes-Brown, Atiya Kai. 2012a. 'America's Shifting Color Line? Reexamining Determinants of Latino Racial SelfIdentification.' Social Science Quarterly 93: 309-22.

Stokes-Brown, Atiya Kai. 2012b. The Politics of Race in Latino Communities: Walking the Color Line. New York: Routledge.

Swarns, Rachel. 2004a. 'Hispanics Debate Racial Grouping by Census.' New York Times, October 24 p. 1.

Swarns, Rachel. 2004b. 'National Briefing.' New York Times, November 23, p. 1.

Tafoya, Sonya. 2002. 'Mixed Race and Ethnicity in California.' Pp. 102-15 in The New Race Question: How the Census Counts Multiracial Individuals, edited by Joel Permann and Mary C. Waters. New York: Russell Sage Foundation.

Tafoya, Sonya. 2003. 'Latinos and Racial Identification in California.' California Counts: Population Trends and Issues 4: $1-15$. 
Tafoya, Sonya. 2004. Shades of Belonging: Latinos and Racial Identity. Washington, DC: Pew Hispanic Center.

Taylor, Paul, Mark Hugo Lopez, Jessica Hamar Martinez and Gabriel Velasco. 2012. When Labels Don't Fit: Hispanics and Their Views of Identity. Washington, DC: Pew Hispanic Center.

Telles, Edward E. 2004. Race in Another America: The Significance of Skin Color in Brazil. Princeton, NJ: Princeton University Press.

Telles, Edward E. and Edward Murguia. 1992. 'The Continuing Significance Of Phenotype Among MexicanAmericans.' Social Science Quarterly 73: 120-2.

Telles, Edward E. and Edward M Murguia. 1990. 'Phenotypic Discrimination and Income Differences Among Mexican Americans.' Social Science Quarterly 71: 683-96.

U.S. Bureau of the Census. 1980. 'General Social and Economic Characteristics' Part 1, US Summary, PC80-1-C1. [Online]. Retrieved on 3 September 2012 from: http://www2.census.gov/prod2/decennial/documents/ 1980a_usC-01.pdf

U.S. Bureau of the Census. 1990. 'General Population Characteristics: United States.' CP-1-1. [Online] Retrieved on 3 September 2012 from: http://www.census.gov/prod/cen1990/cp1/cp-1-1.pdf

U.S. Secretary of the Interior. 1853. The Seventh Census: Report of the Superintendent of the Census for December 1 1852 (to Which Is Appended the Report for December 1, 1851). Printed by Order of the House of Representatives of the United States. Washington, DC: Robert Armstrong, Public Printer

Vaquera, Elizabeth and Grace Kao. 2006. 'The Implications of Choosing 'No Race' on the Salience of Hispanic Identity: How Racial and Ethnic Backgrounds Intersect among Hispanic Adolescents.' Sociological Quarterly 47: 375-96.

Vargas-Ramos, Carlos. 2012. 'Migrating Race: Migration and Racial Identification among Puerto Rican.' Ethnic and Racial Studies: 1-22. iFirst Article, doi: 10.1080/01419870.2012.672759.

Wade, Peter. 1997. Race and Ethnicity in Latin America. Chicago, IL: Pluto Press.

\section{Further Reading}

Bailey, Benjamin H 2002. Language, Race, and Negotiation of Identity: A Study of Dominican Americans. New York: LFB Scholarly.

Candelario, Ginetta B 2007. Black Behind the Ears: Dominican Racial Identity From Museums to Beauty Shops. Durham, NC: Duke University Press.

Dowling, Julie. A. forthcoming. On the Borders of Identity: Mexican Americans and the Question of Race. Austin, TX: University of Texas Press.

Emeka, Amon and Jody Agius Vallejo. 2011. 'Non-Hispanics with Latin American Ancestry: Assimilation, Race, and Identity among Latin American Descendants in the US.' Social Science Research 40: 1547-63.

Itzigsohn, Jose. 2009. Encountering American Faultines: Race, Class, and Dominican Experience in Providence. New York: Russell Sage Foundation.

Jimenez, Tomas R. 2010. Replenished Ethnicity: Mexican Americans, Immigration, and Identity. Berkeley, CA: University of California Press.

Marrow, Helen 2011. New Destination Dreaming: Immigration, Race, and Legal Status in the Rural American South. Stanford, CA: Stanford University Press. 16; 17

Martin, Elizabeth. 2002. 'The Effects of Questionnaire Design on Reporting of Detailed Hispanic Origin in Census 2000 Mail Questionnaires.' Public Opinion Quarterly 66: 582-93.

Morning, Ann 2011. The Nature of Race: How Scientists Think and Teach About Human Difference. Berkeley: University of California Press.

Oropesa, R.S., Nancy S. Landale and Meredith J. Greif. 2008. 'From Puerto Rican to Pan-Ethnic in New York City.' Ethnic and Racial Studies 31: 1315-39.

Qian, Zhenchao. 2004. 'Options: Racial/Ethnic Identification of Children of Intermarried Couples.' Social Science Quarterly 85: 746-66.

Robbin, Alice 2000a. 'Classifying Racial and Ethnic Group Data in the United States: The Politics of Negotiation and Accommodation.' Journal of Government Information 27: 129-56. 23.

Telles, Edward and Vilma Ortiz. 2009. Generations of Exclusion: Mexican Americans, Assimilation, and Race. New York: Russell Sage Foundation.

Vasquez, Jessica M. 2011. Mexican Americans Across Generations: Immigrant Families, Racial Realities. New York: New York University Press. 